\title{
Evaluation of the Home-based Rehabilitation Program Based on CBR Model Through In-depth Interviews With Visiting Physical Therapists
}

\author{
Minyoung Lee', Jinjoo Chung ${ }^{2}$, Hye Jung Hong ${ }^{3}$, Bum Chul Yoon ${ }^{1}$ \\ 'Department of Physical Therapy, College of Health Science, Korea University, Seoul; ${ }^{2}$ nstitute for Society \& Health, Seoul; ${ }^{3}$ Jung-gu Public Health \\ Center, Seoul, Korea
}

Purpose: This study was conducted in order to explore home visiting therapists' self-perceived role, problems, and supplement points of the home-based rehabilitation (HR) program based on the community-based rehabilitation (CBR) model.

Methods: Four home visiting physical therapists, who conducted the HR program, participated in this study. After completion of the HR program, in-depth interviews were conducted using a semi-structured questionnaire for participants to explore their self-perceived role, problems, and supplement points of the HR program.

Results: Participants regarded the role of the HR program as for "the linkage between recipient \&t society", "maintenance \&t improvement of recipients' physical function", and "education of recipient about the way of self rehabilitation". The problems and supplement points were derived from all phases of the HR program, including "human \& material resources", "training program for human resources for HR service", "selection of recipient of HR service", "contents of the intervention for HR service", and "duration of HR service".

Conclusion: These findings indicate that participants well recognized the intention of the HR program based on the CBR model, and suggest that high-quality human resources with rich expertise and experiences, a training program for HR service led by experts, and selection of recipients led by experts are necessary for an effective HR program. In addition, strategies and capacities specified to HR service should be identified, and applied to the training program for human resources for HR service. The results of this study could provide useful information when the government decides on the next guideline for home visiting health service.

Keywords: Community-based rehabilitation, Home-based rehabilitation program, In-depth interview, Qualitative analysis

\section{서 론}

1978년 세계보건기구(World Health Organization, WHO)는 알마아타 선언을 통해 '일차보건의료 (primary health care)'의 중요성을 강조하 였다. 즉, 육체적, 정신적 및 사회적으로 최적의 안녕 상태를 보장하기 위한 보건은 지역사회 내의 모든 주민에게 접근이 용이하며, 이용가 능하고, 적절한 수준으로 활용될 수 있어야 하고, 이는 국가의 보건의 료체계에 포함되어야 한다는 것이다. 이에 따라 1981년 $\mathrm{WHO}$ 는 지역 사회중심재활 (community-based rehabilitation, CBR)을 제안하였고, 이후 CBR사업은 80-90년대에 걸쳐 세계적으로 양적 성장과 함께, 초 기의 '의학적 서비스 중심에서 교육, 사회적 재활, 장애예방 등을 포함 하는 '포괄적 접근'으로 개념적 변화가 일어났다.'
이와 같은 세계적 추세에 발맞추어 우리나라 보건복지부는 $\mathrm{CBR}$ 사업을 "보건소를 중심으로 지역사회의 인적 물적 자원을 최대한 개 발, 활용하여 재활서비스를 체계적으로 구축 제공함으로써 장애인 의 재활촉진 및 사회참여 증진을 도모하는 것"으로 정의하고, 1990년 대부터 $\mathrm{CBR}$ 사업에 대해 보건소를 중심으로 교육을 실시하는 등의 활동을 전개해왔다. ${ }^{2}$ 또한 2013 년부터는 $\mathrm{CBR}$ 사업을 지역사회 통합건 강증진사업의 일환으로 진행하고 있으며, 그에 따라 2014년에는 전국 거점 보건소 중 $44.5 \%$ 에 해당하는 113 개 보건소에서 $\mathrm{CBR}$ 사업을 시범 적으로 운영하였고, 2017 년까지는 전국의 총 255 개 거점 보건소에 확 대 실시할 예정으로 있다. ${ }^{2}$

한편, 방문재활사업은 국가가 장애인의 재활을 위해 가장 적극적 으로 지역사회에 개입하는 CBR사업의 한 형태로써, 보건의료 전문인
Received January 17, 2015 Received February 8, 2015

Accepted February 9, 2015

Corresponding author BumChul Yoon

E-mail yoonbc@korea.ac.kr
Copylight (C) 2015 The Korean Society of Physical Therapy

This is an Open Access article distribute under the terms of the Creative Commons Attribution Non-commercial License (Http:// creativecommons.org/license/by-nc/3.o.) which permits unrestricted non-commercial use, distribution, and reproduction in any medium, provided the original work is properly cited. 
력이 건강문제를 가진 가구 및 가구원을 방문하여 직접 보건의료 서 비스를 제공하거나 관련 기관에 연계하는 형식으로 이루어진다. ${ }^{3}$ 국 내에는 1990년대부터 CBR의 이념적 토대 아래 도입되어 일부 지역에 서 수행되어 왔으며, 연구자들에게도 많은 주목을 받아, 그간 다수의 연구를 통해 그 도입의 필요성과 방법-8, 방문재활사업에 대한 노인 및 장애인의 높은 요구도 ${ }^{911}$ 와 신체기능 향상 효과 ${ }^{12-15}$ 가 제시되어 왔 다. 이와 같은 연구결과에도 불구하고, 방문재활사업의 전국적 도입 은 여전히 국가적 과제로 남아 있었는데, 이는 방문재활사업에 따르 는 보건의료인력의 확보, 방문전문인력의 육성, 그리고 그로 인한 비 용적 부담 등과 같은 현실적인 문제 때문이었던 것으로 보인다. 하지 만, 2013년에 CBR사업이 보건복지부에서 추진하는 지역사회 통합건 강증진사업 내에 포함됨에 따라 $\mathrm{CBR}$ 사업 중 핵심사업인 방문재활사 업도 2017년까지 전국 보건소에서 각 지역의 현황에 맞게 확산 적용 될 새로운 국면에 들어서게 되었다. ${ }^{2}$

방문재활사업의 전국적 확산이라는 새로운 국면에 대비하여 정부 와 관계기관들은 그간 인력 확보와 지침마련 등의 준비를 진행해왔 다. 보건복지부는 2011년에 방문재활사업을 위한 전문인력 2,750명(서 울시 324 명)을 확보하였다고 발표한 바 있다. ${ }^{16}$ 보건복지부와 한국건 강증진재단 및 국립재활원 등 복지부 산하기관은 2001년 이후 지속 적으로 방문재활사업 대상자 선정 기준, 서비스 내용, 전문인력 역할 정의 등을 위한 지침2,16,17과 업무 매뉴얼3을 개발하여 보건소를 중심 으로 한 방문재활사업 수행기관에게 보급해 왔다. 뿐만 아니라, 국립 재활원은 방문건강관리사업을 위한 전문인력 양성을 위해 교육자료 를 발간하고, 오프라인 교육을 진행하고 있다.

그러나, 보건복지부 및 복지부 산하기관에서 보급한 이와 같은 방 문재활사업 관련 업무 지침과 방문전문인력 양성을 위한 교육 프로 그램은 아직 적은 적용사례와 관련 연구의 미흡으로 인해 그 실효성 을 충분히 검증받지 못하고 있다. 2017년까지 CBR사업이 전국 보건 소에 확대실시 됨에 따라 점차 많은 보건소에서 방문재활사업을 수 행하게 될 것임을 고려했을 때, 현재 보건복지부 및 복지부 산하기관 에서 제시한 지침에 따른 방문재활사업이 가지는 문제점과 보완점을 조속히 확인하고, 지속적으로 보완해 나가는 것은 절실히 필요한 활 동이다.

그러므로, 본 연구에서는 $\mathrm{CBR}$ 사업과 관련한 보건복지부 및 복지 부 산하기관에서 제시한 지침을 준수한 서울시 $\bigcirc \bigcirc$ 구의 방문재활 사업 적용사례에 대하여 심층면접을 통한 질적 연구방법을 이용하 여 방문물리치료사가 주관적으로 인식하고 경험한 방문재활사업의 문제점 및 보완점을 확인하고자 한다. 질적 연구방법은 연구자가 설 정한 가설을 검증하는 것을 목적으로 하는 양적 연구방법과는 달리, 연구대상자의 시각에서 그들의 경험에 대한 이해를 얻음과 동시에, 그와 같은 경험이 가지는 의미를 도출하고자 하는 경우 적절한 방법
이 될 수 있다.18,19 선행연구에서 물리치료사 및 간호사 등 전문가 그 룹이 주관적으로 인식하는 방문재활서비스 도입의 필요성에 대해 심 층면담을 이용하여 보고한 바 있다. ${ }^{5}$ 또한, 방문재활서비스를 수급한 장애인을 대상으로 방문재활서비스에 대한 요구도를 심층면담을 통 해 분석한 사례가 있다. ${ }^{10}$ 그러나 방문재활사업에 대한 현 지침의 문 제점과 보완점에 대한 연구는 미비하다.

본 연구 결과를 통해 정부기관은 2017년까지 CBR사업을 전국적으 로 확산시킴에 앞서 업무 지침 및 방문전문인력 양성 교육 프로그램 에서 보완되어야 할 사항을 확인할 수 있을 것으로 사료된다. 뿐만 아 니라 CBR사업 이행주체인 보건소들도 본 연구결과를 통해 방문재활 사업을 처음 시작했을 때 발생할 수 있는 위험요인을 확인하고, 이에 대해 사전에 대처할 수 있을 것으로 판단된다.

\section{연구방법}

\section{1. 연구절차}

본 연구는 $\bigcirc \bigcirc$ 구 보건소에서 주관하는 2014년도 $\mathrm{CBR}$ 사업 중 방문 재활사업의 문제점 및 보완점을 방문 물리치료사 관점에서 분석하기 위해 진행되었다. 보건소, 보건지소 및 종합사회복지관에 소속된 4 명 의 방문물리치료사는 지역에 거주하는 장애인을 대상으로 8 주간 방 문재활활동을 수행하였다. 방문재활활동 기간이 종료된 이후 연구 자들은 방문물리치료사를 대상으로 방문재활활동에 대한 인식과 문제점 및 보완점에 대해 개별 심층면담(in-depth interview)을 진행하 였고, 그 결과를 질적 연구방법을 이용해 도출하였다. 본 연구에서 질 적 연구방법은 방문물리치료사의 주관적인 경험을 심층적으로 분석 하기 위한 방법으로 적용되었다.

\section{2. 연구참여자}

연구참여자는 방문재활활동에 참여한 4 명의 방문물리치료사이다. 연구참여자 선정기준은 $\bigcirc$ 구에서 활동하는 방문물리치료사로, 최소 5 년 이상의 임상경력을 가진 자로 하였다. 본 연구는 모든 연구 참여자들의 서명 동의 하에 진행되었고, $\bigcirc \bigcirc$ 대학교 윤리심의위원회 의 심의를 취득하였다.

\section{3. 방문재활활동}

Figure 1 은 $\bigcirc$ 구의 CBR사업의 일환으로 수행된 방문재활활동의 전 단계와본 연구의 흐름도를 제시하고 있다.

\section{1) 지역사회협의체 및 방문재활팀 구성}

$\bigcirc$ 구 보건소는 보건복지부와 국립재활원의 2013년 CBR사업 운영 지침에 따라 보건소 및 보건지소, 장애인복지관, 종합사회복지관, 데 


\begin{tabular}{|c|}
\hline Form a community consultative group \\
\hline $\begin{array}{l}\text { A community consultative group composed of experts belonging to the } \\
\text { community rehabilitation centers \& institutes was formed }\end{array}$ \\
\hline$\downarrow$ \\
\hline Plan a HR program* \\
\hline $\begin{array}{l}\text { The community consultative group planed the HR program as follows: } \\
\text { - Formed the HR team composed of four physical therapists } \\
\text { - Determined the selection criteria for recipients } \\
\text { - Determined the way of finding recipients } \\
\text { - Determined the duration \& number of times of the HR service }\end{array}$ \\
\hline$\downarrow$ \\
\hline Plan the specific activities for the HR service \\
\hline $\begin{array}{l}\text { HR team planed the following specific activities for the HR service } \\
\text { - Determined the recipients } \\
\text { - Determined the physical therapist in charge of each recipient } \\
\text { - Determined the types of intervention for the HR service }\end{array}$ \\
\hline$\downarrow$ \\
\hline Provide the HR services for the recipients \\
\hline $\begin{array}{l}\text { HR team provided the HR services for ten recipients for one hour a day, one } \\
\text { time a week, for eight weeks }\end{array}$ \\
\hline$\downarrow$ \\
\hline Conduct the in-depth interviews \\
\hline $\begin{array}{l}\text { After completion of the HR program, researchers conducted the in-depth } \\
\text { interviews with the physical therapists }\end{array}$ \\
\hline
\end{tabular}

Figure 1. The flowchart of HR activity based on CBR model. $\mathrm{HR}$, home-based rehabilitation; CBR, community-based rehabilitation. *HR program was planned in accordance with "guideline for the community-based health promotion program” by National Rehabilitation Center, 2013.

이케어센터, 장애인자립생활센터, 구청 그리고 $\bigcirc \bigcirc$ 대학교 소속의 연 구원으로 구성된 지역사회재활협의체(이하 ‘협의체')를 결성하고, 세 차례의 회의를 거쳐 다음과 같은 사항을 결정하였다: (1) 방문물리치 료사 선정, (2) 방문재활 대상자 선정기준 및 발굴 방법, (3) 방문재활 기간 및 횟수. 선정된 방문물리치료사는 협의체의 하위 기구인 방문 재활팀의 팀원으로써 방문재활활동을 계획 및 이행하였다.

\section{2) 방문재활 대상자 선정기준 결정 및 발굴}

방문재활대상자의 장애유형은 2013년 $\bigcirc \bigcirc$ 구에 등록된 총 장애인 $(6,102$ 명) 중 첫 번째( 3,154 명), 그리고 시각장애인에 이어 세 번째(648 명)로 높은 비율을 차지하는 지체장애와 신경계 질환자로 제한하였 다. ${ }^{18}$ 방문재활대상자 선정 기준은 협의체의 결정에 따라 기초생활수 급자 및 차상위계층 중 건강위험군 및 질환군으로 하였으며, 방문재 활대상자 발굴은 장애인복지관 소속의 사회복지사, 종합사회복지관 소속의 방문재활팀, 보건지소 소속의 방문간호사로부터 의뢰받거나, 혹은 장애인자립생활센터에서 장애인 및 그 보호자로부터 직접 방 문재활 서비스 수급을 신청받는 형식으로 하였다. 이와 같은 선정기
준 및 대상자 발굴활동은 2013년 CBR사업 운영 지침에 부합한다. ${ }^{2}$ 방 문재활대상자에는 2 명의 지체장애인과 9 명의 신경계 질환 장애인이 포함되었다. 방문재활대상자의 연령대는 50 대에서 10 대까지로 다양 하게 분포되어 있었고, 대부분의 경우 기초생활수급자이거나(2명) 차상위계층(8명)으로 경제적 어려움을 호소하였다.

\section{3) 방문재활팀 방문재활활동 계획}

방문재활팀은 두 차례의 회의를 통해 각 방문물리치료사가 담당할 대상자와 구체적인 방문재활활동 중재방법을 결정하였다. 협의체는 방문재활팀에게 근력운동을 위한 고무밴드와 통증치료를 위한 휴대 용 경피신경자극치료기와 기능적전기자극치료기를 지급하였다.

\section{4) 방문재활 서비스 제공}

방문재활팀의 결정에 따라 방문재활 서비스는 2014년 5월부터 7월 사 이에 회당 1 시간, 주 1 회, 총 8 주간 진행되었다. 이는 정기관리 대상자 에게 분기별 1 회 이상의 정기 서비스를 제공하도록 가이드 하는 2013 년 $\mathrm{CBR}$ 사업 운영 지침을 상회하는 횟수이다. 방문재활 서비스 내용 으로는 관절가동 운동, 근력운동, 통증치료, 자가 재활운동 교육 등 이 수급자의 상태와 요구에 맞게 진행되었다.

\section{4. 자료수집}

질적 연구 경험이 있는 1 명의 연구원이 연구참여자를 대상으로 개별 심층면담을 진행하였다. 개별 심층면담은 참여자가 선호하는 시간 에, 연구참여자의 근무지에서, 연구자와 연구참여자와의 직접 대면 으로 수행되었다. 연구참여자 1 인당 1 회에서 2 회 이상의 면담을 수행 하였고, 1 회 면담 시간은 1 시간 30 분가량 소요되었다. 모든 면담 내용 은 참여자의 동의 하에 녹취되었다.

심층면담은 연구자가 반구조화된 면담지를 사용하여 개방적 질 문을 하고, 연구참여자가 이에 대해 자유롭게 응답하는 형식으로 수 행되었다. 질문 범주는 다음과 같다: (1) “지난 8주간의 방문재활 활동 은 무엇을 위한 것이라고 생각하십니까?”, (2) “방문재활 활동을 수행 하는 과정에서 문제점 혹은 보완점이 있다고 느끼셨다면, 그것은 무 엇입니까?”

\section{5. 자료분석}

본 연구는 질적 연구방법을 사용하여 분석하였다. 19,20 질적 연구방법 은 일반화와 대표성을 강조하는 양적 연구와 달리 인간의 경험, 인식, 의미를 파악하는 데 유용한 방법으로, 본 연구의 목적인 방문 물리치 료사의 경험과 이들이 방문재활활동에 대해 가지는 의미를 이해하 는 데 적합한 방식이다. 세 명의 연구자들이 녹취된 면담내용을 모두 필사하였으며, 필사 자료가 완성된 이후에는 모든 연구자가 각자 진 
술된 자료를 반복적으로 읽어나가면서 탐색하고자 하는 현상과 관 련된 부분에 밑줄을 그어 가며, 의미 있는 진술을 도출하였다. 각자가 의미 있는 진술을 도출한 후에는 연구자들 간의 논의를 통해 도출된 의미를 주제와 범주로 분류 및 조직하는 작업을 거쳤다. 이 과정에서 연구자들 사이에 타당성이 합의되지 않거나, 혹은 연구자들 간에 이 견이 있는 자료들은 다시 재분류 및 조직화하는 과정을 거쳐서 관심 있는 현상에 대해 통합적으로 기술하고자 하였다. 마지막으로 분석 결과의 타당도 검증을 위하여 참여자에게 분석된 자료를 설명하여 그 내용의 적절성을 확인하는 과정을 거쳤다. ${ }^{21}$ 본 연구에서 심층면 담 및 자료 분석은 임상경력 10 년 이상의 물리치료학과 교수 1 인과 다 년간의 질적 연구 경험을 가진 사회학 박사의 1 인의 지도 하에 진행되 었다.

\section{결 과}

\section{1. 연구참여자 특성}

연구참여자의 연령은 30-40대였다. 물리치료사 경력은 최대 20년에 서 최소 6년, 방문재활활동 경력은 최대 5년부터 최소 8 주로 편차가 컸다. 연구참여자 중 1 인은 남성이었으며, 3 명은 여성이었다. 연구참여 자 $\mathrm{A}$ 는 $\bigcirc \bigcirc$ 구 보건소에 소속되어 있으면서 방문재활팀의 총책임자 로써 활동을 위해 필요한 지원 물품을 파악하여 방문재활팀에게 조 달하고, 활동 내용을 협의체에 보고하는 역할을 수행하였다. 연구참 여자 $\mathrm{A}$ 와 $\mathrm{C}$ 는 국립재활원에서 방문전담인력 양성을 위한 사전 교육 을 수강하였으나, 연구참여자 $\mathrm{D}$ 는 방문물리치료 선임을 통한 1 일간
의 인수인계 이외에 별도의 사전 교육은 받지 않았고, 연구참여자 B 는 사전교육을 수강하지 않았다. 연구참여자들의 인구사회학적 특 성과 임상 경력은 Table 1에 제시되어 있다.

\section{2. 방문재활 서비스에 대한 인식}

연구참여자들은 방문재활활동이 '사회화의 연결고리', 신체기능 유 지 및 개선', '자가 재활훈련 방법 교육을 위한 것으로 인식하고 있었 다(Table 2).

\section{1) 사회와의 연결고리}

대부분의 연구참여자들은 방문재활을 신체적 기능 회복만을 위한 것이 아닌, 방문재활대상자가 스스로를 사회의 일원'이라고 생각하 게 하고, 사회와 소통할 수 있는 공간을 만들어 주기 위한 활동으로 인식하고 있었다.

"이분들이 운동을 해서 갑자기 좋아지고 이런 게 일차적인 목표가 아니고, 아무도 관심을 갖고 있지 않은 분들을 찾아가서 사회의 일원 이라고 생각하게 하고, 자신이 관심을 받고 있다고, 느끼게 하는 것이 가장 중요한 목적이라고 생각해요" (연구참여자 A)

"이분들이 저소득층이기도 하고 자존감이 조금 낮은 경향이 있어 서 계속 대화를 하고 상담을 하면서 이분들 스스로 본인에 대한 자 존감도 높이고, 사회와 더 소통할 수 있는 공간을 만들 수 있는 그런 것도 조금 있다는 생각이 들었어요" (연구참여자 D)

Table 1. Sociodemographic characteristics \& clinical experiences of the participants

\begin{tabular}{|c|c|c|c|c|c|c|c|c|}
\hline $\mathrm{ID}^{*}$ & Sex & $\begin{array}{l}\text { Age } \\
\text { (year) }\end{array}$ & $\begin{array}{c}\text { Current } \\
\text { working place }\end{array}$ & $\begin{array}{c}\text { Clinical } \\
\text { experience: } \\
\text { place (year) }\end{array}$ & $\begin{array}{c}\text { HR } \\
\text { experience } \\
\text { (month) }\end{array}$ & $\begin{array}{c}\text { Training } \\
\text { institute }^{+} \\
\text {place (day) }\end{array}$ & $\begin{array}{l}\text { Diseases of } \\
\text { recipient }^{*}\end{array}$ & $\begin{array}{c}\text { Age of } \\
\text { recipient }^{\S} \text { (year) }\end{array}$ \\
\hline \multirow[t]{4}{*}{ A } & $\mathrm{F}$ & 43 & Community & Community & 2 & National & Stroke & 76 \\
\hline & & & health center & health center & & rehabilitation & Poliomyelitis & 54 \\
\hline & & & & $(20)$ & & institute & Cat's cry syndrome & 14 \\
\hline & & & & & & (1) & Cerebral palsy & 12 \\
\hline \multirow[t]{3}{*}{$B$} & M & 40 & Community & Rehabilitation hospital, & 2 & None & Stroke & 79 \\
\hline & & & health center & community health center & & & Spine injury & 56 \\
\hline & & & & (16) & & & & \\
\hline \multirow[t]{4}{*}{ C } & $\mathrm{F}$ & 33 & Branch office of & Branch office of & 10 & National & Physical disabilities & 76 \\
\hline & & & the community & the community & & rehabilitation & Physical disabilities & 35 \\
\hline & & & health center & health center & & institute & Spine injury & 79 \\
\hline & & & & (6) & & (3) & & \\
\hline \multirow[t]{3}{*}{$D$} & $\mathrm{~F}$ & 35 & Social & General \& private hospital, & 60 & Social & Stroke & 67 \\
\hline & & & welfare center & social welfare center & & welfare center & Stroke & 77 \\
\hline & & & & $(10)$ & & (1) & & \\
\hline
\end{tabular}

HR, home-based rehabilitation; $F$, female; $M$, male.

*indicates the code of participant; ' indicates the place (and days) where participants received training for HR service; ${ }^{*}$ indicated the disease of each recipient for whom participants provided HR service; §indicated the age of each recipient for whom participants provided HR service. 


\section{2) 신체기능 유지 및 개선}

방문재활활동의 궁극적인 목적은 병원에서의 치료 목적과 크게 차 이가 없이, 신체기능의 유지나 관절구축의 예방 등을 위한 것으로 인 식하고 있었다.

"일단 치료적인 것은 병원에 있을 때랑 똑같죠. 결국에는 환자가 더 이상 관절 구축이 안 일어나고 보행을 하셔도 조금 더 편하게 하실 수 있도록 환자에게 이제 치료적인 방향으로 생각을 하는 게 있고요" (연 구참여자 D)

\section{3) 자가 재활훈련 방법 교육}

지속적인 재활을 위해 방문재활대상자 스스로가 재활훈련을 할 수 있도록 교육시키는 과정으로 인식하고 있는 연구참여자도 있었다.

"저희가 맨날 갈 수 있는 게 아니니까, (제가) 못 갈 경우에 계속 자 기 (스스로) 재활훈련을 할 수 있도록 교육을 하는 그런 방향(으로 생 각합니다)" (연구참여자 $\mathrm{B}$ )

\section{3. 방문재활활동의 문제점 및 보완점}

연구참여자들은 방문재활활동을 위한 인적·물적 자원, 방문전문인
력 양성 교육, 방문재활활동 계획, 서비스 제공 등 방문재활활동 전 단계에 걸쳐 문제점 및 보완점이 있는 것으로 인식하고 있었다. Table 3 은 이와 같은 문제점과 보완점을 활동 단계 순으로 제시하고 있다.

\section{1) 인적 ·물적 자원}

인적자원에서는 전문성과 경력을 갖춘 고급인력의 필요성, '팀' 접근 방식의 필요성, 팀당 2 명 이상의 인력 배치 필요성, 방문물리치료사 수의 부족 등이 주요한 범주로 도출되었다. 방문물리치료사로는 물 리치료사 경력이 '5년 이상' 혹은 ' 10 년 이상'이고, '질환별 접근'이 가 능한 전문성과 경력을 고루 갖춘 고급인력이 적절하다는 의견이 대 다수였고, 이와 같은 활동을 간호사나 운동처방사와 같은 타 전문가 가 수행하기에는 많은 어려움이 따를 것으로 예상하였다.

"치료사로 봤을 때 가장 고급인력이 투입되어야 될 자리거든요. 병 원에서는 (치료대상자가) 정해진 케이스에 대해 '이거 해주세요' 하고 오는 사람들이잖아요. 근데 여기(방문재활)에는 뭘 요구해야할 줄 모 르는 사람이 오거든요. (그러니까, 치료사가 훈련이 되어 있지 않으면) 그냥가서 (치료)흥내만 내고 오는 경우도 많고......" (연구참여자 B)

"기본적으로 질환별 접근을 잘 할 수 있는 그런 역량 같은 것이 필

Table 2. Theme and categories of the participants' self-perceived role of the HR program

\begin{tabular}{ll}
\hline Theme & \multicolumn{1}{c}{ Category } \\
\hline Self-perceived role of the HR program & The linkage between recipient \& society \\
& Maintenance \& improvement of the physical function \\
& Education of recipient about the way of self rehabilitation \\
\hline
\end{tabular}

$H R$, home-based rehabilitation.

Table 3. Themes and categories of the participants' self-perceived problems \& supplement points about HR program

\begin{tabular}{ll}
\hline Theme & \multicolumn{1}{c}{ Category } \\
\hline Human \& material resources & A necessity for high-quality human resources with rich expertise \& experiences \\
& A necessity for a team approach \\
& A necessity for an arrangement of more than two experts at once \\
& A shortage of manpower for HR service \\
& A necessity of supports for means of transportation \& expenses \\
Training program for human resources for HR service & A necessity for an education led by expert \\
& A necessity for an education program held in each community \\
Selection of recipient of HR service & A necessity for the selection of recipient led by expert \\
& A necessity for refinement of the selection criteria of recipient \\
Contents of the intervention for HR service & A necessity for a standard protocol for HR service \\
& A necessity for an attitude of mind as service provider \\
& A necessity for strategies for inducing motivation \& friendliness of recipient \\
& A necessity for a safety management to prevent accidents \\
& A necessity for an education for guardians \& caregivers \\
The duration of HR service & A necessity for a continuous HR service \\
\hline
\end{tabular}

HR, home-based rehabilitation. 
요해요. (그게 안되니까) 쉬운 거(훈련) 위주로만 가고, 제가 역량이 부 족하다는 걸 느꼈어요" (연구참여자 C)

"운동 치료를 좀 해본 사람이 훨씬 더 효과적이죠. 근데, 저희 경험 많은 물리치료사가 하면서도 좀 힘든 면도 있고, 좀 더 전문적으로 들 어가야 되는 부분이 많은데, 뭐 간호사나 운동처방사가 방문재활활동 을 한다는 거는 횔씬 더 힘들 거라고 생각이 되요...... 그리고 (방문재 활활동의) 근본 취지에도 맞지 않는다고 생각하고요" (연구참여자 $\mathrm{A}$ )

방문물리치료사의 업무범위를 벗어나는 부분에 대해서는 타 전문 가와 협업이 가능하도록 '팀' 접근방식이 필요하다는 의견이 있었다.

"환경적인 부분에 대해 개선이 필요하다 싶은 데가 있어도, 그 부 분을 지원을 해줄 수 있는 방법이 없으니까, 아무래도 팀으로 (운영) 되면 조금 더 나을 수도 있을 거 같아요. 뭐 간호사랑 다른 전문 인력 으로 팀이 되어서......"(연구참여자 C)

연구참여자 중 몇몇은 물리치료사와 대상자 모두의 신변안전을 위해 두 명 이상의 물리치료사가 한 팀을 이루어 방문재활을 수행할 필요성을 제시하였다.

"요즘 사회적으로 성적인 문제도 많고, 특히 장애인분들 같이 스스 로가 자기를 보호할 수 없는 분들한테 (물리치료사가) 가는 경우도 많고, 역으로 그분들(장애인들)이 물리치료사한테 유해를 가할 수도 있는 문제도 충분히 있어요. 남자들끼리만 사는 집도 있고, 정신적으 로 불안정한 분들도 있잖아요. 그래서 제가 보기에는 항상 복수조가 필요한 것 같아요" (연구참여자 $\mathrm{B}$ )

"현재로써는 (방문물리치료사의) 양도 안되고 질도 안 되는 게 문 제” 라는 의견도 있었다. 또한, 물적 자원에 대해서는 교통수단 및 교 통비 지원이 필요하다고 인식하고 있었다.

"이게 참 좋은 사업인데 예산이 되게 많이 측정돼야 할 것 같아요. 이동을 하는 거잖아요. 그러면 교통수단이 제일 문제예요. 치료사가 자기 차를 끌고 다니면서, 기름값을 자기가 내면서 (방문재활활동을) 하는 건 무리잖아요" (연구참여자 $\mathrm{B}$ )

\section{2) 방문전문인력 양성 교육}

방문전문인력 양성 교육과 관련해서는 전문가에 의한 양성 교육의 필요성과 권역별 교육의 활성화가 주요한 범주로 도출되었다. 국립재 활원에서 시행된 사전 교육을 이수한 연구참여자들은 교육 내용이
실제 방문재활활동에 크게 도움이 되지 못하였고, '전문가(물리치료 사)에 의한 보다 전문적인 양성 교육이 필요하다고 언급하였다.

"방문재활 부분만(을 위해) 따로 물리치료사를 위한 교육이 있었 으면 싶은데, 국립재활원에서 물리치료사가 교육하는 경우는 되게 드물어요. 그리고 (교육이) 있다고 해도 굉장히 그 비율이 적고 뭐..... 한 두 시간..... 그 짧은 시간에 케이스 바이 케이스로 아주 다 양한 환자들과 장애 등급, 유형에 대해 다 하는 거도 좀 무리고......" (연구참여자 $\mathrm{A})$

"제가 (교육을) 두 번 받았거든요. 한번은 재활사업에 대해서 그냥 총체적으로 어떻게 하는지 하고, 한번은 방문재활 전반적인 것에 대 해 저희가 이미 다 알고 있는 거 있잖아요. 관절가동범위운동이나 기 본적인 것들..... 간호사선생님들한테는 도움이 되었을지 모르겠지 만, 저희는 이미 알잖아요...... 거의 그런 내용이었어요." (연구참여자 C)

권역별 교육, 즉 국립재활원에서의 교육 이외에 각 $\mathrm{CBR}$ 사업 단위 로 방문물리치료사양성 교육을 활성화시킬 필요성도 제기되었다.

"국립 재활원에서 하는 것도 괜찮은데, 권역별 재활 병원이 있기도 하니까 각 지역별로 굉장히 이걸 많이 활성화시키면 좋을 것 같아요 저희 재활협의체 내에 있는 선생님들만이라도 같이 모여서 치료적인 면, 애로 사항이나, 실질적으로 재활운동을 하면서 (느낀 점들을) 좀 공유하면 좋을 것 같아요. 그리고 교육도 자체적으로 보건소 내에 있 는 치료사 선생님이나, 할 수 있는 분들이 해서 하려고 장기적으로는 생각하고 있어요"(연구참여자 $\mathrm{A})$

\section{3) 방문재활대상자 선정}

방문재활대상자 선정과 관련해서는 전문가에 의한 대상자 선정의 필 요성과 현 보건복지부의 방문재활대상자 선정기준의 재정비가 주요 한 보완점으로 도출되었다. 방문전문인력 간에 방문재활대상자 선정 에 대한 판단 기준이 다르기 때문에, 실제로 방문재활 서비스를 제공 할 전문가 집단이 직접 방문재활 대상자를 선정하는 것이 적절하다 는 의견이 있었다.

"물리치료 대상자에게는 제가 나가고, 도시락을 원하시는 분은 사 회복지사가 나가고, 사례관리가 필요할 때는 상담반이..... 그렇게 나갈 수 밖에 없는 게 포커스가 틀려요. 사회복지사 선생님은 식생활 에 대해 (수급자가) 지금까지 어떻게 하고 계셨는지를 파헤치신 다음 에 다른 걸 하니까 (조사하니까) 본인한테 필요하신 걸 잘 가져가시거 든요. 보는 시각 자체가 틀리니까 아마 사회복지사 선생님이 저희 쪽 
것까지 상담을 다 해오시면 저희는 다시 가서 또 물어봐야 되겠죠. 이 런 부분이 틀린 건 어쩔 수 없는 것 같아요" (연구참여자 D)

한편, 이번 방문재활활동에서는 물리치료사가 아닌 사회복지사나 간호사에 의해 방문재활 대상자 선정이 이루어졌기 때문에, 대상자 에 대한 충분한 사전 정보 없이 재활활동을 시작해야 하는 어려움이 있었다는 의견이 있었다.

"일단 가면 환자들에 대한 정보가 없어요. 환자들이 골다공증 문 제나 다른 신체적인...... 뭐 디스크가 심할 수도 있는 거고, 그런 특성 을 전혀 모르는 상태에서 치료를(해야 하니까).....처음에는 치료로 바로 들어가기가 힘들어요" (연구참여자 B)

또한, 현재의 보건복지부의 방문재활대상자 우선순위 지침(저소 득층, 재가중증장애인 우선)에 대해 보완이 필요하다는 의견도 있었 다. 즉 '장애의 심각도'가 주요한 선정기준인 것에는 동의하나, 개선의 여지가 많고, 스스로 개선의지와 만족도가 높은 중등도' 장애인도 포 함되는 것이 적절하다는 의견이 있었다. 또한 '발병 초기'이거나, 경제 적인 여건은 괜찮으나 다른 이유로 '의료지원에 대한 접근성'이 떨어 지는 경우, 혹은 연령대가 '70대 이하인 경우도 대상자로 고려되어야 한다고 하였다.

"중증 장애인들도 (방문재활이) 필요하지만 짧은 기간에도 잠재력 이 많은 분들, 조금만 해주면 정상군으로 전환될 가능성이 많으신 분 들도 (방문재활이) 되게 필요하다고 생각해요, 조금만 하면 되는데 그걸 잘 모르고 집안에만 있는 거예요. 그런 분들은 지역사회로 더 쉽 게 나올수 있으니까....." (연구참여자 A)

"(장애 심각도가) 중등도일 경우에는 운동치료 효과도 되게 빨리 나타나고, (물리치료사가) 해줄 수 있는 것도 많아요. 실제로 그분들 도 더 좋아하고, 바뀌니까..... 중환자실에서 치료받아야 할 수준이 아니라, 말 그대로 '피지컬한 것을 요구하시는 분들한테 물리치료가 필요한 거죠" (연구참여자 $\mathrm{B})$

“(선정 기준이) 딱딱 이렇습니다' 라고 할 수 없는 게 그때그때마다 상황이 너무 다양하세요. 아들이 7-8명인데 아무도 안 도와주는 경 우도 있어서...... 일단은 '의료지원에 대한 접근성이라는 것도 중요해 요. 그러니까 이분이 경제적인 사정은 괜찮아도 집에서 아무도 돌봐 주는 사람이 없다, 그래서 운동하자고 하실 분이 아무도 안 계신다고 하면 저희도 어느 정도 수준에서 (방문재활활동) 계획을 해요." (연구 참여자 $\mathrm{D})$
"발병이 되고 나서 바로 치료를 못하신 분들이 되게 많아요. 그래 서 초기에 (경제적) 여건이 안 되시는 분들에 대한 지원이 필요해요. 그러니까 그렇게 오래 지속되신 분들 말고 한 2-3년 안이나....." (연구 참여자 $\mathrm{C})$

"일단 동기 부여 면에서 너무 고령이신 분들보다는 못해도 70대 전 (정도로) 연령이 조금 낮은 게 나을 거 같아요" (연구참여자 C)

\section{4) 방문재활 서비스 내용}

방문재활 서비스의 내용과 관련한 보완점으로는 표준화된 프로토콜 의 필요성, 서비스 제공자로써의 마인드의 필요성, 재활동기 및 친근 감 유발 전략의 필요성, 사고 예방 안전 관리의 필요성, 보호자 혹은 간병인 교육의 필요성 등이 도출되었다. 연구참여자들은 현재의 보 건복지부 지침은 정기관리 대상자에 대해서 최소한의 서비스 제공 횟수와 평가에 대해서만 필수 이행사항으로 정의하고 있으나, 그 외 에 ‘표준화된 프로토콜’이 있어야 보다 실질적인 효과를 볼 수 있을 것이라는 의견을 제시하였다.

"처음에 딱 방문재활 시작할 때 어떤 식으로 이루어져야 되는지 좀 표준화된 프로토콜이 있는 상황에서 거기서 케이스 바이 케이스로 들어가는 게 좋은데, 지금 전국적으로도 시행되는 거 보면 그냥 정기 관리자에 대해서 일년에 네 번만 가서 전후 평가하고, 방문재활하는 건데 이거 갖고는 전혀 뭘 기대할 수 없거든요. 이 사업이 실질적으로 효과를 보거나 현장에서 뿌리를 내리려면 그런 것들이 조금 더 체계 를 잡아가야 된다고 생각을 해요. 하나의 보건소 단위가 아니라 좀 큰 단위에서 지침이 구체화되어야 한다고 봅니다" (연구참여자 $\mathrm{A}$ )

또한, 방문재활대상자를 환자가 아닌 서비스 사용자로 대하는 자 세가 필요하다고 인식하였다. 이는 서비스 사용자를 위한 적절한 매 너와 응대방법이 방문전문인력 양성 교육 프로그램에 추가될 필요 가 있음을 의미한다.

"기업에서 친절교육 하듯이 우리도 환자들을 (대하는 방법을 배워 야 해요). 근데 저희가 병원에서 주로 생활했기 때문에 저도 환자를 대한다는 개념을 버리기가 되게 힘들어요" (연구참여자 B)

대다수의 연구참여자는 수급자의 신체 향상을 위한 훈련에 앞서 방문재활대상자의 재활동기를 유발시키거나 친밀감을 높이기 위한 활동이 필요하다고 인식하고 있었다.

"환자가 자기 몸을 그렇게 할 줄 몰라서 안 했을까요? 그렇지 않아 
요. 일단 동기가 떨어지고 자기가 아파서 안 움직였고, 그러다 보니 더 안 움직이게 되고 하는 거지" (연구참여자 B)

"처음에 가서 이 분들과 바로 친해지는 게 더 힘들어요.. 잘 하다가 이제 자기는 안 한다고 하시는 분들도 있고...... 왜냐하면 아무래도 동기도 떨어지고, 우울증이 되게 심하신 분들도 많고, 낯가림도 되게 심하고......(그러니까) 첫 날 가서 뭐 평가하고 이런 거 보다는 친해지는 것을 최우선적으로 해야 될 것 같고...... 계속 몸과 손을 만지고 이렇게 신체를 접촉하는 거 있잖아요" (연구참여자 A)

한편, 물리치료사 경력이 15 년 이상인 B와, 방문재활 경력이 5년 이 상인 연구참여자 $\mathrm{D}$ 는 방문재활활동은 병원과 같이 사고에 바로 대 처할 수 있는 여건이 안되므로 안전에 대해 충분히 유의를 하여야 한 다는 특성이 있다고 언급하였다. 그리고 방문물리치료사가 사고를 피해갈 수 있는 역량'을 갖출 필요가 있다고 하였다.

"병원에서 하는 거랑 여기서(방문재활) 하는 거랑 약간 차이가 날 수밖에 없는 게 병원은 운동시설이 다 같이 갖추어져 있는데 집에는 아예 그런 게 없으니까 최대한 병원보다 조금 더 조심스럽게 접근을 하는 경향을 보이고 있거든요. 예를 들어 병원이었으면 일어나서 할 수 있는 부분(훈련)도 조금 더 조심해서 운동을 시키고..... 안전에 관 련해서 신경 써야할 부분이 더 많죠" (연구참여자 D)

“물리치료사들이 기본적으로 병원에서 근무를 한 경험이 있던가 운동치료를 해본 경험이 있어서 기본적으로 사고를 피해갈 수 있는 역량이 첫 번째로 되야 될 것 같아요. (치료를) 많이 제공할 수 있는 것 도 중요하지만 일단 안전이 확보가 되어야 하니까요. 그리고 치료사 의 안전도 확보되어야 하고요" (연구참여자 B)

몇몇 연구참여자는 방문물리치료사는 하루 종일 치료를 할 수 없 으므로, 보호자 혹은 간병인이 재활훈련에 관심을 보이는 경우에는 이들을 교육시키는 것이 효과적인 방법이라고 하였다.

“제 생각에 가장 효과적인 방법은 보호자 교육이에요. 왜냐하면 제가 있는 시간은 길어봤자 1 시간인데 보호자는 거의 24 시간 붙어 계 시기 때문에 보호자가 약간 그런 데(재활훈련)에 관심이 있으신 경우 에는 그분들을 공략하는 게 가장 (효과적이에요)" (연구참여자 D)

"요양보호사들은 본인이 이분을 케어해야한다는..... 그런 것들을 돈을 받고 하시는 분들이라서 더 잘해주시는 것 같아요. (제가 담당 하는) 할머니를 간호하는 요양보호사 한 분은 운동을 어떻게 해야
하는 건지 저한테 물어 보고, 본인도 조금 시켜보시고 운동 해주시는 분도 있어요. 그분께서 선생님 오실 때 운동 열심히 하시라고 할머니 옆에서 계속 애기를 해요. 근데 그게 다는 아니에요. 보호자라고 다 같은 보호자는 아니시더라고요" (연구참여자 D)

\section{5) 방문재활 서비스 기간}

모든 연구참여자들은 총 8 회의 방문재활 횟수는 실질적인 효과를 확인하기에는 부족하다고 인식하고 있었고, 이와 같이 짧은 횟수로 방문재활활동을 수행하게 되는 이유로는 부족한 방문재활인력이 언 급되었다.

"이번에는 썩 만족스럽지는 않지만 1년에 8 회 정도만 하고 일단은 끝나잖아요. 그리고 내년 같은 경우에도 연 8회(서비스를 제공하고), 그 다음 월 1회씩 모니터링을 할 생각인데...... 왜냐하면 인력이 일단 부족하니까 하다 보면 이것마저도 힘들어지거든요. 인력 보강이 되 어서 조금 더 체계적으로 좀 했으면 싶고, 가장 아쉬워하는 부분이...... 이제 기간인 거죠" (연구참여자 $\mathrm{A}$ )

\section{고 찰}

본 연구에서는 보건복지부의 $\mathrm{CBR}$ 사업 프로세스와 지침을 준수 한 서울시 $\bigcirc \bigcirc$ 구의 방문재활사업 시범 적용사례를 통해 방문물리 치료사 관점에서 방문재활활동의 문제점 및 보완점을 검토하고자 하 였다. 그 결과 연구참여자들은 방문재활활동 전 단계에 걸쳐 문제점 및 보완점이 있는 것으로 인식하고 있음을 확인할 수 있었다.

연구참여자들은 이번 방문재활활동이 CBR 모형에 기반하여 수행 되었음을 인식하고 있었다. 즉, 연구참여자들은 이번 방문재활활동 이 '사회와의 연결고리'와 '신체기능 유지 및 개선' 두 가지 모두를 위한 것으로 인식함으로써 장애인의 재활촉진 및 사회참여 증진을 도모 하고자 하는 보건복지부의 $\mathrm{CBR}$ 사업 취지 ${ }^{2}$ 를 이해하고 있었음을 알 수 있다. 이와같은 결과는 연구참여자들이 CBR 모형에 대한 올바른 이해 하에 방문재활활동의 문제점과 보완점을 도출하였음을 검증해 주고 있다.

방문물리치료사의 자격요건에 대해서 연구참여자들은 최소한 5 년에서 10 년 정도의 물리치료 경력이 있고, 다양한 질환을 다루어 본 경험이 있는 고급인력이 필요하다고 언급하였다. 그 이유로는 방문재 활활동 시에는 병원에서 치료를 수행할 때 보다 다양한 질환을 가진 대상자들을 접하게 되고, 또한 대상자들이 본인의 문제를 명확하게 인지하고 있지 못한 경우가 많아 물리치료사가 다양한 질환을 가진 대상자의 상태를 직접 판단할 수 있는 역량을 갖추고 있어야 하기 때 문이라고 하였다. 물리치료사로 활동한 경력이 6년인 연구참여자 C 
조차도 본인은 “쉬운 거(훈련) 위주” 로만 치료하게 되고, 스스로 "역 량이 부족하다"는 것을 느꼈다는 언급은 이와 같은 연구결과를 뒷받 침하고 있다. 한편, 방문물리치료사로써의 자격기준으로 본 연구에 서 도출된 '5년에서 10 년 정도'의 물리치료 경력'은 '3년 이상의 임상경 험이 적절하다고 보고된 $\mathrm{Kim}^{6}$ 의 연구결과 보다 높은 수준이다. 이와 같은 차이는 본 연구의 결과는 연구참여자가 방문재활활동에 직접 참여한 이후 심층면담을 통해 도출된 것에 비해, 선행연구 결과는 방 문재활을 수행한 경험이 없는 물리치료사들로부터 도출되었기 때문 으로 판단된다. 즉, 연구참여자가 실제 방문재활활동을 수행해 본 결 과, 예상보다 더 어려움이 느껴졌던 것으로 추측된다. 이와 같은 연구 결과에도 불구하고, 현 보건복지부의 방문재활사업 지침에는 방문 물리치료사를 비롯한 방문전문인력에 대한 자격기준이 명시되어 있 지 않아 방문재활활동의 질적 저하가 우려된다.

방문재활활동을 수행하기에 앞서 수강한 국립재활원 교육에 대해 서 연구참여자들은 교육 내용이 방문재활사업에 대한 총괄적 설명 이거나 물리치료 개요 수준에 머무르고 있어, 방문재활 현장에서 실 제로 도움이 되는 내용이 아니라고 언급하였고, 이는 방문물리치료 사 양성 교육이 물리치료사가 아닌 사회복지사나 간호사에 의해 진 행되었던 점에 기인한 것으로 판단하고 있었다. 또한, 현 보건복지부 지침에서 방문전문인력 양성을 위한 사전 교육 수강이 방문재활활 동 수행을 위한 필수요건으로 정의되어 있지 않은 점도 문제가 있는 것으로 보인다. 따라서 방문물리치료사를 양성하기 위한 교육은 물 리치료에 대한 심도 깊은 이해와 풍부한 임상적 지식을 겸비한 물리 치료사에 의해 수행되어야 할 것으로 판단되고, 이와 같은 양성 교육 의 수강은 물리치료사가 방문재활활동을 수행하기 위한 필수요건으 로 정의되어야 할 필요성이 있다.

방문재활대상자 선정 기준에 대해서는 저소득층 및 중증장애인 에게 우선권을 부여하고 있는 현재의 보건복지부 지침 이외에 고려 되어야 할 사항이 다양하게 도출되었다. 예를 들어 '중등도' 장애인, '발병 초기 장애인' 에서 개선효과가 크게 나타날 가능성이 있고, 대 상자의 개선의지와 만족도도 큰 경향이 있으므로 대상자에 포함시 키는 것이 바람직하다는 의견이 있었다. 또한 저소득층이 아닌 경우 에도 '의료지원에 대한 접근성'이 떨어지는 경우에는 대상자에 포함 시킬 필요가 있으며, 연령대가 70대 이상인 경우에는 개선의지가 떨 어지는 경향이 있으므로, 70 대 이하 장애인에게 우선적으로 방문재 활을 수행하는 것이 효과적일 것이라는 의견이 있었다. 한편 제공자 가 아닌 수요자인 장애인 입장에서 방문재활서비스에 대한 요구도를 조사한 Chois와 Yoon ${ }^{9}$ 의 연구결과, 소아 장애아동의 보호자 중 $90 \%$ 는 방문재활 서비스 수급을 희망한 것으로 나타났다. 또한, $\mathrm{Jang}^{10}$ 의 연 구에서 사고 후유증과 만성질환 후유증을 않고 있는 281 명의 장애인 중 $84.3 \%$ 는 $\mathrm{CBR}$ 사업에의 참여를 희망하는 것으로 나타났다. 따라서,
본 연구결과와 방문재활에 대한 장애인들의 높은 요구도를 고려했 을 때, 현 보건복지부의 방문재활대상자 선정기준을 조금 더 유연하 게 정의하되, 대상자에게 제공하는 서비스 형태는 장애상태와 경제 적 여건 등에 따라차별화시키는 방향을 제안해볼 수 있을 것이다. 또 한, 대상자의 경제적 여건에 따라서는 유료 방문재활 서비스를 제공 하여, 장애인들의 방문재활 요구도를 만족시키는 방안도 고려해볼 필요가 있다.

방문재활대상자 발굴 절차에 대해서는 보건복지부 지침에서 권 고하는 바에 따라 지역사회의 여러 기관에 소속된 사회복지사, 방문 간호사, 혹은 방문재활팀이 방문재활대상자로 의뢰한 자에 대해 재 활 서비스를 제공하였으나, 그 결과 재활의지가 없거나 개선의 여지 가 많지 않은 자가 대상자로 선정된 경우가 있었다는 점이 문제점으 로 대두되었는데, 이는 방문재활대상자를 의뢰한 각 보건의료 전문 가마다 장애인의 문제를 보는 관점이 다른 것에서 기인된 것으로 보 인다고 제시하였다. 따라서, 방문재활의 효과를 높이기 위해서는, 일 차적으로는 보건의료 전문가별 역할정의를 명확히 하고, 이차적으로 는 타 보건의료 전문가 집단으로부터 방문재활대상자를 의뢰받은 경우에도 최종적인 대상자 적절성 여부는 서비스를 제공하게 될 전 문가 집단이 판단하도록 하는 것이 바람직할 것으로 판단된다.

방문재활 서비스 내용과 관련해서는 방문재활활동은 물리치료사 가 병원에서 환자를 치료하는 것과는 차별화되어야 할 부분이 있으 며, 그에 따라 방문물리치료사는 일반 물리치료사와는 차별화된 역 량을 갖추어야 한다는 의견이 제시되었다. 예를 들어 방문재활대상 자의 경우에는 본인 스스로 개선에 대한 의지가 없거나, 자존감이 낮 은 경우가 많으므로 방문물리치료사는 '치료사가 아닌 서비스 제공 자로서의 마인드를 가지고, 친절하고 친근감 있게 대상자를 대할 필 요가 있으며, 치료에만 집중하기보다는 재활동기를 유발시키는 전략 개발에 초점을 맞출 필요가 있다고 하였다. 또한 방문재활활동은 병 원과는 달리 대상자의 가택에서 수행하게 되므로, 물리치료사는 항 상 안전에 만전을 기할 필요가 있고, 위험한 상황에 대처할 수 있는 역량을 갖출 필요가 있다고 하였다. 이와 같은 연구 결과는 방문전문 인력 양성을 위한 교육 프로그램 내용이 보완될 필요성이 있음을 암 시함과 동시에, 병원에서의 물리치료행위와는 차별화되는 방문재활 활동에 대한 직무분석 작업이 필요함을 시사한다. 최근 $\mathrm{Yu}^{22}$ 의 박사 학위 논문으로 가정방문 물리치료사의 직무분석에 관한 연구가 수 행된 바 있어 고무적이다. 향후 본 직무분석 내용 중 응급처치'와; '대 상자와 가족에 대한 정서적 지지' 등 방문재활에 특화된 직무들에 대 한 구체적인 수행방안이 연구되어, 그 연구결과가 방문물리치료사 양성 교육 내용에 추가되고, 실제 방문재활 현장에 적용될 것을 제안 하는 바이다.

마지막으로, $\bigcirc \bigcirc$ 구에서 실시된 8 주간 총 8 회의 방문재활 서비스 
는 보건복지부에서 정기관리 대상자에게 권고하는 분기별 4 회를 상 회하는 기간임에도 불구하고, 대부분의 연구참여자는 실질적인 효 과를 확인하기에는 부족한 횟수라고 하였다. 그러므로 향후 효과적 인 방문재활활동을 위해 방문물리치료사의 추가적인 확보 등 지속 적인 방문재활활동을 위한 방안이 마련되어야 할 것으로 보인다.

결론적으로 방문재활은 풍부한 경력과 다양한 경험을 갖춘 물리 치료사에 의해 수행되어야 하며, 방문물리치료사 양성을 위한 교육 및 방문물리치료 대상자 선정은 물리치료사에 의해 수행되는 것이 방문재활사업의 효과를 높일 수 있는 방법인 것으로 보여진다. 또한 방문재활 서비스 중에는 병원에서의 치료와는 차별화되는 부분이 있 으므로, 이를 위해 필요한 전략과 역량이 식별되고, 이를 반영한 방문 물리치료사 양성 교육 프로그램이 마련되어 방문물리치료사에게 제 공될 필요가 있을 것으로 사료된다. 본 연구의 결과가 보다 나은 서비 스 제공을 위해차후의 $\mathrm{CBR}$ 사업에 적극적으로 반영될 필요가 있다.

\section{REFERENCES}

1. Word Health Organization. Community-based rehabilitation Guidelines. 2010.

2. National Rehabilitation Center. Guideline for the community-based integrated health promotion program. 2013.

3. Ministry for Health, Welfare and Family Affairs. Manual for physical therapy in customized home visiting health service. 2009.

4. Jung DI, Kim CK, Ko DS. The survey of awareness and necessity on introduce home physical therapy in the long-term care insurance. KoCon. 2014;14(6):298-306.

5. Lee MS, Kim MC, Kim GY. A study for home-based physical therapy service introduction through a group of professionals in-depth interview. J Korean Soc Phys Med. 2013;8(3):303-15.

6. Kim GY. A study on the introduction of home-based physical therapy rehabilitation service. Eulji University. Dissertation of Doctoral Degree. 2013.
7. Ahn CS, Yu WJ. A study of management and satisfaction for home visiting physical therapy. J Korean Soc Phys Med. 2012;7(3):241-50.

8. Son KH, Kim EK, Kim SM. Research about necessity of visiting home physical therapy. KPTSA. 2012;19(1):27-38.

9. Choi S, Yoon J. Awareness and demand for pediatric home-based physical therapy in Korea. Phys Ther Kor. 2013;20(3):62-73.

10. Jang MS. Needs for activation of community based rehabilitation (CBR): qualitative study and questionnaire survey. Inje University. Dissertation of Doctoral Degree. 2013.

11. Yi C, Weon J, Ok J. House visits by physical therapist and patient needs. Phys Ther Kor. 2000;7(1):64-78.

12. Park SK, Heo JW, Yang DJ, et al. Effects of home visiting physical therapy and environmental factors analysis using international classification of functioning, disability and health (ICF). J Kor Phys Ther. 2012; 24(4):282-9.

13. Park SK, Ji HY, Heo JW. Effects of home visiting physical therapy on activities of daily living and function in disabled persons living at home. J Kor Phys Ther. 2011;23(2):61-8.

14. Kim SM, Song JM. The efficacy of community-based rehabilitation exercise to improve physical function in old women with knee arthritis. J Kor Phys Ther. 2010;22(1):9-17.

15. An D. Effects on improvement of activities of daily living through shortterm home visiting physical therapy. Phys Ther Kor. 2007;14(2):53-60.

16. Korea Health Promotion Foundation. Guideline for home visiting health service. 2013.

17. Ministry for Health, Welfare and Family Affairs. Guideline for customized home visiting health service. 2008.

18. Creswell JW. Qualitative inquiry and research design: Choosing among five approaches. Los Angeles, Sage, 2007.

19. Krefting L. Rigor in qualitative research: The assessment of trustworthiness. Am J Occup Ther 1991;45(3):214-22.

20. Jung-gu office. Current situation of registration of each type of the disabilities. 2013.

21. Norman K. Denzin, Lincoln YS. Collecting and interpreting qualitative materials. Thousand Oaks, Calif., Sage, 1998.

22. Yu WJ. A study on the job analysis of the home visiting physical therapist. Eulji University. Dissertation of Doctoral Degree. 2014. 